\title{
仲間に関する幼児の性格特性概念
}

\author{
林智幸'＼cjkstart湯澤正通 広島大学
}

\section{What dimensions do young children's trait concepts have for peers?}

\author{
Tomoyuki Hayashi and Masamichi Yuzawa (Hiroshima University)
}

\begin{abstract}
This study investigated what dimensions young children's trait concepts have for real peers at their nursery school. Teachers of nursery school rated children's personality characteristics in terms of each dimension of the Big Five, and children were selected who showed different behavioral characteristics in those the five dimensions. Five- and six-year-old children ( 26 participants: 14 boys and 12 girls) evaluated those selected peers' personality. It was found that young children made different evaluations between extroversion and the other four traits (agreeableness, conscientiousness, emotional stability, and intellect), and between agreeableness and intellect. The results suggested that young children's trait concepts have a dimension of extroversion, in addition to a general dimension of goodness-badness.
\end{abstract}

Key words: trait, young children, Big Five, peers.

The Japanese Journal of Psychology

2006, Vol. 76, No. 6, pp. 554-559

人間生活を営む上で他者の行動を予測する能力は必 要不可欠である。他者の行動予測を効率的に行うため に，他者に想定する安定的な行動傾向を一般に“性 格”と呼ぶ。このような他者性格の認知能力は，幼い 時期から見られることが分かっている。

幼児の性格認知に関する研究はこれまで数多く行わ れている(林, 2004; Heller \& Berndt, 1981; Yuzawa \& Harano, 1996)。初期の代表的研究の一つとして, Heller \& Berndt（1981）が挙げられるが，彼らによる 5-18 歳の幼児・児童を対象とした研究において，5 歳児でも提示された物語を予測の根拠として用いてい たことは，幼児が性格特性の一貫性を理解しているこ とを示唆している。

Yuzawa \& Harano（1996）は，4-6歳児を対象に 四つの異なる場面において実在（実験参加児自身）・ 架空の人物に対する優しい・意地悪な・どちらでもな い（中立的）仲間の行動予測をそれぞれ行わせた。分

Correspondence concerning this article should be sent to: Tomoyuki Hayashi, Graduate School of Education, Hiroshima University, Kagamiyama, Higashi-Hiroshima 739-8524, Japan (e-mail: thayashi@hiroshima-u.ac.jp)

本論文のデータは, 2003 年度広島大学教育学部心理学科に 提出された宇野有紀子氏の卒業研究に基づいています。使用許 可を下さった宇野有紀子氏, ご指導, ご助言を賜りました松田 文子先生をはじめとする教育心理学研究室の皆様に深謝申し上 げます。最後に, 本研究のための調査にご協力賜りました川上 中部保育所の先生方, 青組の園児の皆さん, 広島大学教育学部 心理学科の学部生の皆さんに厚く感謝申し上げます。
析の結果，4歳児は意地悪な仲間よりも優しい仲間の 行動を優しいと予測し，5，6歳児は中立的な仲間よ りも優しい仲間の行動を，意地悪な仲間よりも中立的 な仲間の行動をそれぞれ優しいと予測する傾向にあっ た。また，行動の対象が架空の人物ではなく実在の人 物（実験参加児自身）であった場合に 4 歳児が意地悪 な仲間をより一貫して意地悪だと予測していた。

これらの研究は, 幼児の性格特性概念が, 成人のそ れと同様, 状況を通して一貫していることを示してい る。しかし, 他方で, 幼児の性格特性概念が, 成人の それと異なり，内容的に未分化であることを示唆する 研究が行われている。林（2004）は，幼児の性格特性 概念に関する研究が性格の特定の次元のみを取り上げ てきたことを批判した（例えば，“優しい”，“意地 悪”：Yuzawa \& Harano, 1996 ; “寛大”，“利已的”： Heller \& Berndt, 1981)。そして, 性格がビッグ・ファ イブと呼ばれる広範な五つの特性によって包括的に記 述可能であるとする “ビッグ・ファイブ”説に基づ き，ビッグ・ファイブ場面に扔ける幼児の行動予測能 力と彼らの特性概念の内容について検討した。具体的 に, 幼児に物語を提示し, その登場人物の別の場面に 打ける行動予測を行わせ（研究 1), またその登場人 物の性格特性を判断させた（研究 2)。その結果, 5, 6 歳児は, 複数の場面で一貫した行動の予測を行う が, 五つの特性次元を明確にせず，ポジティブーネガ ティブのような単一の次元で他者の性格を判断してい ることが示唆された（例えば，元気な子に関して，別 
の場面で元気な行動を行うと予測するが，同時に，優 しく，頭がよいと判断する)。

しかし，林（2004）の結果から“幼児は末分化なビ ッグ・ファイブ概念しかもっていない”と結論づける のは早急である。なぜなら，判断の対象が物語の登場 人物という架空の存在だったために経験や想像力にお いて未熟な幼児には未分化な判断しかできなかった可 能性も考えられるからである。幼児の性格認知に関す る他の多くの研究も架空の人物の行動予測という方法 を採用している (Heller \& Berndt, 1981)。確かにこの ような方法を用いれば予測の対象となる人物の性格を 自由に統制でき，幼児の言語能力の未熟さもカバーで きる。しかし, Yuzawa \& Harano（1996）の研究で は予測の対象が架空である場合よりも実在である場合 の方が幼児は適切に予測を行っていることが指摘され ていた。また, 林 (2004) の研究 2 では, 行動予測で はなく, 架空の人物の性格特性を抽象的な性格形容詞 によって直接評定させたため, 幼児にとって困難であ ったことも考えられる。

そこで本研究では, 実在の人物（ここでは，保育所 のクラスの仲間で，担任保育士によってその性格特性 を評定された者）を対象に，ビッグ・ファイブの次元 に対応する行動の予測をさせることにした。幼児の性 格概念がポジティブーネガティブのような単一の次元 から構成され，幼児がそれに基づいて仲間の行動を予 測しているならば，同一の仲間によるポジティブな行 動（例えば，外向性の行動と協調性の行動）は，大人 （担当保育者）によって異なる評定が行われていても， 幼児によって同じように予測されるはずである。一 方, 架空の人物を対象とした場合と異なり, クラスの 仲間との日常的なかかわりの経験によって，幼児であ っても，ビッグ・ファイブのいずれかの次元を相互に 区別している可能性が考えられる。もし幼児がビッ グ・ファイブの次元を相互に区別しているならば，そ れらの次元に関して担任保育士が異なった評定を行っ た仲間（例えば，“外向性”が高く，“協調性”が低 い）に対して，同様に，異なった評定を行うことが予 想される。

\section{方法}

\section{予備調査}

幼児を対象とした調査ではクラスの仲間の 5 特性に ついて評価してもらうが，その際に5 特性を幼児に理 解できるように表現したものが必要となる。また，そ れらの表現は可能な限り当該特性のみの要素を純粋に 代表し，それ以外の要素は含まれていないものでなけ ればならない。そして，実在の仲間を評価してもらう ため，ネガティブなイメージを誘発しやすいネガティ ブな表現を用いないことを配慮した。そこで調査者側
の主観に基づいたさまざまな表現を用意し，それらを 大学生に評定してもらった ${ }^{2}$ 。調查の対象が幼児であ ることを考慮し, 表現の内容は観察可能な行動とし た。評定の方法は, 各表現に五つの特性の要素がそれ ぞれどの程度含まれているかを両極にポジティブ特性 とネガティブ特性を配した 5 段階尺度を用い，5特性 すべてについて評定してもらうというものであった。 ポジティブ特性に“非常によくあてはまる”を+2 点, “わりとあてはまる”を+1 点, “どちらともいえ ない”を 0 点，ネガティブ特性に“非常によくあては まる”をー2 点, “わりとあてはまる”をー1点として 評定を得点化し, 得点の平均值・標準偏差を算出し た。調査用紙とともに村上・村上（1999）による5 特 性の定義を配布し，それを参考にさせることで評定者 の主観的なビッグ・ファイブを統制して評定の客観性 が高まるよう努めた。表現の採用基準を，(a) 当該特 性の得点の平均值が +1 点から+2 点の範囲にあるこ と, (b) それ以外の 4 特性の得点の各平均值が -1 点 から+1 点の範囲にあること, (c) (当該特性の得点の 平均値) - (それ以外の 4 特性の得点の各平均值) $\geqq 0.5$ であることとし，すべての表現が(a)から (c) を満たす まで修正を加えながら繰り返し評定を行った。5 回目 の評定で採用基準を満たした 5 種類の表現がすべて揃 つたが，確認のために同じものを再度評定してもらい (最終調査), さらに各表現が最も強く表していると思 われる特性を 5 特性のなかから一つだけ選んでもらつ た。後に, 選んだ特性の評定者内での一致率を算出し た。最終的に採用した各表現についての最終調查にお ける得点の平均值・標準偏差, および特性の一致率を Table 1 に示した。

\section{本調査の方法}

参加者 保育園に通う年長児 26 名（男児 14 名, 女 児 12 名）で，平均年齢は 5 歳 11 力月，年齢の範囲は 5 歳 8 力月から 6 歳 7 カ月であった。実施時期は 11 月であった。

特性判断の対象の選別 まず，保育園の担任保育士 に園児一人ひとりにおける5特性について評価しても らった（5段階評定。“全くあてはまらない”，“あま りあてはまらない”,“どちらともいえない”,“わりと あてはまる”, “非常にあてはまる”の $1-5$ 点)。その 際の 5 特性については, 予備調査で吟味した, ネガテ イブイメージを誘発しにくいポジティブな 5 種類の表 現を用いた。担任保育士による評定を“成人による分 化した判断”とみなし，これを参考に参加者全員のな

\footnotetext{
2 本研究は, 成人の対人認知モデル（ビッグ・ファイブ的対 人認知モデル）を認知発達の到達点と想定し，それが幼児期に どのように理解されているかを検討することを目的としている。 そのため, ビッグ・ファイブ的対人認知モデルを理解し, 保持 していると考えられる大学生を対象に予備調査を行った。
} 
Table 1

最終調查における評定の平均・標準偏差及び特性の一致率（\%)

\begin{tabular}{|c|c|c|c|c|c|c|c|}
\hline \multirow{2}{*}{ 項 目 } & & \multicolumn{5}{|c|}{ 特 性 } & \multirow{2}{*}{ 一致率 } \\
\hline & & 外向性 & 協調性 & 勤勉性 & 情緒安定性 & 知性 & \\
\hline \multirow{2}{*}{$\begin{array}{l}\text { お外で走りまわって遊ぶ } \\
\text { (外向性) }\end{array}$} & 平均値 & 1.95 & 0.32 & 0.47 & 0.42 & 0.16 & \multirow[t]{2}{*}{100} \\
\hline & 標準偏差 & 0.23 & 0.48 & 0.61 & 0.51 & 0.5 & \\
\hline \multirow{2}{*}{$\begin{array}{l}\text { お友達が这いていたらなぐさめてあげる } \\
\text { （協調性） }\end{array}$} & 平均值 & 0.84 & 1.79 & 0.47 & 0.89 & 0.42 & \multirow[t]{2}{*}{89.5} \\
\hline & 標準偏差 & 0.83 & 0.42 & 0.61 & 0.66 & 0.61 & \\
\hline \multirow{2}{*}{$\begin{array}{l}\text { きちんとお片づけをする } \\
\text { (勤勉性) }\end{array}$} & 平均値 & -0.16 & 0.84 & 1.68 & 0.74 & 0.58 & \multirow[t]{2}{*}{89.5} \\
\hline & 標準偏差 & 0.76 & 0.5 & 0.48 & 0.56 & 0.61 & \\
\hline \multirow{2}{*}{$\begin{array}{l}\text { あまり泣いたり怒ったりしない } \\
\text { (情緒安定性) }\end{array}$} & 平均値 & -0.65 & 0.29 & 0.24 & 1.59 & 0.53 & \multirow[t]{2}{*}{100} \\
\hline & 標準偏差 & 0.7 & 0.59 & 0.44 & 0.62 & 0.51 & \\
\hline \multirow{2}{*}{$\begin{array}{l}\text { なぞなぞがすき } \\
\text { (知性) }\end{array}$} & 平均值 & -0.16 & 0.26 & 0.68 & 0.26 & 1.68 & \multirow[t]{2}{*}{94.7} \\
\hline & 標準偏差 & 0.76 & 0.56 & 0.67 & 0.56 & 0.58 & \\
\hline
\end{tabular}

注）評定者は 19 名（男性 7 名，女性 12 名，平均年齢 21.8 歳）であった。

Table 2

特性判断の対象に対する担任保育士の判定結果

\begin{tabular}{cccccc}
\hline \multirow{2}{*}{ 対 } & \multicolumn{5}{c}{ 象 } \\
\cline { 2 - 6 } & 外向性 & 協調性 & 勤勉性 & 情緒安定性 & 知 性 \\
\hline A & $5^{\text {a) }}$ & $3^{\text {a) }}$ & $2^{\text {a) }}$ & $2^{\text {a) }}$ & $5^{\text {a) }}$ \\
B & $5^{\text {a) }}$ & $3^{\text {a) }}$ & $2^{\text {a) }}$ & $2^{\text {a) }}$ & $5^{\text {a) }}$ \\
C & $5^{\text {a) }}$ & $3^{\text {a) }}$ & 3 & $1^{\text {a) }}$ & - \\
D & $4^{\text {a) }}$ & 4 & 4 & 5 & $2^{\text {a) }}$ \\
E & $4^{\text {a) }}$ & 3 & 4 & 4 & $2^{\text {a) }}$ \\
F & 4 & $3^{\text {a) }}$ & $4^{\text {a) }}$ & $1^{\text {a) }}$ & 5 \\
G & 4 & 2 & $3^{\text {a) }}$ & $1^{\text {a) }}$ & 4 \\
\hline
\end{tabular}

a) 実際に質問した特性。

かから特性判断の対象とする園児を選別した。当初 は, 当該特性のみの得点が高くかつそれ以外の 4 特性 の得点との間に差がある園児を各特性につき 2,3 名 選び出す予定だったが，担任保育士の評価が全体的に ポジティブ方向に偏っていたためそのような条件にあ てはまる園児はいなかった。そこで 5 特性のなかで対 を作り (全部で, ${ }_{5} \mathrm{C}_{2}=10$ 対), その対における得点 差が大きい園児を特性対ごとに 2 名ずつ選んだ。参加 者に対して行う質問の数が最小限になるように, 複数 の特性対にわたって重複して同一の園児を対象として 選んだところ, 最終的に対象は 7 名（男児 3 名, 女児 4 名), 質問数は 22 となった。詳細については Table 2, Table 3 に示した。

手続き 個別面接により行った。調査にかかった時 間は参加者 1 人あたり 10 分程度であった。参加者に は, 各特性を表す 5 種類の行動が, 対象である 7 名に おいてどれぐらいの頻度で観察されるかを小円・中
円・大円が描かれた紙からそれぞれ選択させることで 3 段階評定（“全然”，“ときどき”，“いつも”の 0-2 点）をしてもらった。対象となっている園児が回答者 となった場合は，本人に関する質問のみを除外した。 評価してもらう対象の順序と同一対象内の質問の順序 はランダムにした。

教示 “これから○○ちゃん（対象となっている園 児の名前）についてお話を聞かせてね”と前置きし， 外向性についての質問なら“○○ちゃんはいつも打外 で走りまわって遊んでいるかな？ときどき走りまわ って遊んでいるかな？ 全然走りまわって遊ばないか な?”，協調性なら“○○ちゃんはお友達が泣いてい たらいつもなぐさめてあげるかな？ ときどきなぐさ めてあげるかな？ 全然なぐさめてあげないかな？”, 勤勉性なら“○○ちゃんはいつもきちんとお片づけを するかな？ときどきお片づけをするかな？ 全然お 片づけをしないかな?”, 情緒安定性なら“○○ちゃ 
Table 3

特性対の割り当てと担任保育士の評定における得点差

\begin{tabular}{|c|c|c|c|c|c|c|c|c|c|c|c|}
\hline \multirow{2}{*}{ 対 } & \multirow{2}{*}{ 象 } & \multicolumn{10}{|c|}{ 特性対 } \\
\hline & & 外 >協 & 外＞勤 & 外 $>$ 情 & 外 $>$ 知 & 協＞勤 & 協>情 & 協 $<$ 知 & 勤>情 & 勤 < 知 & 情 $<$ 知 \\
\hline & A & 2 & 3 & 3 & - & 1 & - & 2 & - & 3 & 3 \\
\hline & B & 2 & 3 & - & - & 1 & - & 2 & - & 3 & 3 \\
\hline & C & - & - & 4 & - & - & 2 & - & - & - & - \\
\hline & D & - & - & - & 2 & - & - & - & - & - & - \\
\hline & $E$ & - & - & - & 2 & - & - & - & - & - & - \\
\hline & $\mathrm{F}$ & - & - & - & - & - & 2 & - & 3 & - & - \\
\hline & $G$ & - & - & - & - & - & - & - & 2 & - & - \\
\hline
\end{tabular}

注）数值は担任保育士の評定における実際の得点差を表す。例えば, “外>協”の場合, 対象 A あるいは B の外向性と協調性が特性対の比較対象となる。一はその対において比較される対象ではないことを表 す。

Table 4

参加者における特性判断の平均値の差の検定（片側検定）

\begin{tabular}{|c|c|c|c|c|c|c|c|c|c|c|}
\hline \multirow{3}{*}{ 特性対 } & \multicolumn{4}{|c|}{ 対象 1} & \multicolumn{6}{|c|}{ 対象 2} \\
\hline & \multicolumn{2}{|c|}{ 特性 1} & \multicolumn{2}{|c|}{ 特性 2} & \multirow[t]{2}{*}{$t$ 值 } & \multicolumn{2}{|c|}{ 特性 1} & \multicolumn{2}{|c|}{ 特性 2} & \multirow[t]{2}{*}{$t$ 值 } \\
\hline & 平均值 & 標準偏差 & 平均値 & 標準偏差 & & 平均值 & 標準偏差 & 平均値 & 標準偏差 & \\
\hline 外 > 協 & 1.48 & 0.65 & 0.64 & 0.76 & $4.94^{* * *}$ & 1.40 & 0.65 & 0.64 & 0.64 & $4.57^{* * *}$ \\
\hline 外＞勤 & 1.48 & 0.65 & 0.84 & 0.75 & $3.36^{* *}$ & 1.40 & 0.65 & 1.08 & 0.64 & $1.88^{*}$ \\
\hline 外>情 & 1.48 & 0.65 & 0.96 & 0.89 & $2.98^{* *}$ & 1.68 & 0.56 & 0.80 & 0.65 & $5.28^{* * *}$ \\
\hline 外 $>$ 知 & 1.41 & 0.65 & 1.21 & 0.72 & 1.04 & 1.44 & 0.58 & 1.00 & 0.82 & $1.96^{*}$ \\
\hline 協>勤 & 0.64 & 0.76 & 0.84 & 0.75 & -1.22 & 0.64 & 0.64 & 1.08 & 0.64 & -2.86 \\
\hline 協＞情 & 0.96 & 0.73 & 0.80 & 0.65 & 0.89 & 1.16 & 0.80 & 1.04 & 0.73 & 0.65 \\
\hline 協 <知 & 0.64 & 0.76 & 1.20 & 0.82 & $2.91^{* *}$ & 0.64 & 0.64 & 1.21 & 0.72 & $2.09^{*}$ \\
\hline 勤>情 & 1.40 & 0.65 & 1.04 & 0.73 & $1.67^{+}$ & 1.08 & 0.76 & 0.80 & 0.71 & 1.23 \\
\hline 勤＜知 & 0.84 & 0.75 & 1.20 & 0.82 & $1.47^{+}$ & 1.08 & 0.64 & 1.21 & 0.72 & -0.20 \\
\hline 情 < 知 & 0.96 & 0.89 & 1.20 & 0.82 & 1.06 & 0.80 & 0.65 & 1.21 & 0.72 & -0.49 \\
\hline
\end{tabular}

注）本研究では参加者に二つの対象に対して特性判断をしてもらっている。具体的な対象は Table 3 参照。なお，特性は 1 , 2 は特性対の見出しの順序に相当する。

${ }^{* * *} p<.001,{ }^{* *} p<.01,{ }^{*} p<.05,+p<.10$.

んはいつも泣いたり怒ったりするかな？ときどき泣 いたり怒ったりするかな？ 全然泣いたり怒ったりし ないかな?”，知性なら“○○ちゃんはなぞなぞを出 されたらいつも答えられるかな？ときどき答えられ るかな？ 全然答えられないかな?”とそれぞれ尋ね た。

\section{結 果}

まず，特性判断における参加者の評定値の平均と標 準偏差を算出した。担任保育士の評定を参考にして各 特性対において 2 特性間の得点差が大きい園児を判断 の対象としたが，参加者による判断にも同様な差が見 られるかどうかを検討するため，10特性対における 対象各 2 名についてそれぞれ $t$ 検定を行った（Table 4)。その結果, “外向性 - 協調性”, “外向性 - 勤勉
性”, “外向性・情緒安定性”, “協調性・知性” の 4 対 については 2 名両方に対する判断に有意差が見られ， “外向性・知性”については 1 名に対する判断のみに 有意差が見られた。“勤勉性・情緒安定性”, “勤勉 性・知性”の 2 対については 1 名に対する判断のみに 有意傾向が見られた。そのほかの “協調性・勤勉性”, “協調性・情緒安定性”, “情緒安定性・知性”につい ては 2 名どちらに対しても有意差は見られなかった。

このことから，5，6歳児においては“外向性・協 調性”, “外向性 - 勤勉性”, “外向性 - 情緒安定性”, “協調性・知性” の区別はできており, “外向性・知 性”, “勤勉性・情緒安定性”, “勤勉性・知性” は区別 しつつあると結論づけることができる。また, “協調 性・勤勉性”, “協調性・情緒安定性”, “情緒安定性・ 知性”については区別できているとはいえなかった。 


\section{考察}

本研究の目的は，従来の幼児における性格研究のな かで用いられてきた架空の人物に対する行動予測では なく, 実在の人物に対する行動予測を 5,6 歳児に行 わせ，幼児の特性概念がビッグ・ファイブの次元にお いて相互に分化しているかどうかを検討することであ った。

特性対について予想された差が幼児の判断に見られ るかどうかを検討した結果，“外向性・協調性”，“外 向性・勤勉性”, “外向性・情緒安定性”, “外向性・知 性”, “協調性・知性”の5対において有意差が見られ た。また, “勤勉性・情緒安定性”, “勤勉性・知性” においても有意傾向が見られた。

このように，外向性のみすべての組み合わせに差が 見られたことは，少なくとも，クラスの仲間の性格特 性を判断するとき，幼児が外向性の次元を他の次元か ら区別して評価していることを示唆する。例えば，お 外で走りまわつて遊ぶことが多いことが，必ずしもお 友達が泣いていたらなぐさめてあげることが多いこと を意味しないことを理解している。また，協調性と知 性が区別されており，また勤勉性に関しては分化しつ つあることから, 外向性以外の次元に関しても, 幼児 の特性概念が分化しつつあることが分かる。

林（2004）は，幼児が幼稚園年長児頃から全般的な “良い”次元を内容とした性格特性概念を獲得し，発 達とともに次元を分化させ，最終的に小学生高学年頃 に成人同様ビッグ・ファイブ概念を獲得すると主張し た。本研究の結果は, クラスの仲間に対して, 外向性 次元を他の次元と区別して評定しているなど，架空の 人物に対する場合に比べて早期に，ビッグ・ファイブ の次元を理解していることを示唆する。幼児は, 仲間 との日常的なかかわりの経験から，まさにビッグ・フ アイブの次元を形成し始めていると考えられる。

外向性が他の次元よりも明確に区別されていた理由 として, 外向性が活動性や積極性など, 行動の量に関 連する特性であることが挙げられる。一般に，人は， 他者の行動を見て，その人の行動に影響を与える内的 要因としての性格を推論しているが, その推論には行 動の内容が重要な手がかりとなる。しかし, 外向性の 判断については，行動内容を手がかりとするのではな く，単にその人の観察された行動（その行動がどのよ うな内容かに関係なく）の量のみを手がかりとすれば よい。このように外向性判断は, 他の性格特性の判断 に比べて容易であるため, 外向性次元の獲得も容易で あると考えられる。

ただし，この考えに対して次のような解釈も成り立 つ。そもそも，幼児の日常生活において，外向性の次 元の行動の頻度は多く, その他の次元の行動（例え ば，協調性の次元の“お友達が泣いていたらなぐさめ
てあげる”）は出現頻度が少ない。このため，幼児の 判断は, 本研究で取り上げた特定の外向的行動（お外 で走りまわって遊ぶ）の認識に基づいてるかもしれな い。確かに, 幼児の判断が単に特定の行動の頻度を反 映し，性格特性の理解に基づいていなかった可能性も 考えられる。しかし，林（2004）でも，外向性次元の 評定が他の次元の評定すべてと異なっていたわけでは ないが，いくつかの次元の評定と区別されており，外 向性の判断が性格特性の理解に基づいていないという 可能性は小さいように思われる。今後，実際の行動だ けでなく，外向性の次元を反映した架空の行動（例え ば，架空の挻生日での行動）を予測させるなどの方 法を用いることで, さらに検討を行う必要がある。

以下, 本研究の方法論や結果に対するいくつかの解 釈及び，考えられる今後の検討課題を述べる。本研究 では，外向性以外の次元に関しては，相互に分化して いる明確な証拠が得られなかった。これに関しては, 次のような可能性が考えられる。第 1 に, 幼児の性格 特性概念は, 外向性以外について, 林（2004）の主張 するように，全般的な“良い”次元を内容としている という解釈である。第 2 に, 幼児の性格特性概念は, 外向性以外についても，相互に分化している次元があ るが, 本研究で取り上げた表現が 5 特性を必ずしも適 切に反映していなかった可能性である。この解釈が正 しいならば，今後，5特性に関する表現を工夫しなが ら，検討を行う必要がある。

また，幼児の性格特性概念には，ビッグ・ファイブ とは質的に異なった幼児固有の次元があることも否定 できない。そのような可能性を探るためには，今後， 幼児の行動や言語データを質的に分析する研究が必要 になるだろう。

さらに，本研究では，クラスの実在する仲間につい ては，園児は“普段から交流をもっているため，性格 推論に役立つ情報を得るのが容易である”という仮定 のもとに検討を進めた。しかし年長児では, 男女別久 の仲間を形成することが多いなど，仲間関係によって 相手の性格特性に関する理解が大きく異なっている可 能性がある。そのため, 評価する園児と評定される仲 間との関係を考慮した研究を行うことである。また， 本研究の結果は，対象としたクラスの子どもたちの性 格特性の構造を反映していると考えられる。例えば, 協調性と勤勉性に関する教師評定のばらつきは小さ く，それらの特性に関する個人差が少なかったこと が，特性間の区別を困難にしている可能性がある。 様々なクラスにおける子どもたちの性格特性の構造を 調べることで性格特性次元の分化と経験との関連を検 討することも今後の課題である。

これまでの幼児の性格特性概念の研究では実在人物 を対象とした研究は少ない。今後, 本研究同様に実在 する仲間を対象とする研究が行われるだろう。それら 
の研究をすすめる際には, 本研究における上記の改善 点に留意する必要があるだろう。

\section{引用文献}

林 智幸 (2004). 行動予測から捉えた幼児の性格特 性概念の内容 教育心理学研究, 52, 52-60.

(Hayashi, T. (2004). What dimensions do young children's trait concepts have for the prediction of others' actions? Japanese Journal of Educational Psychology, 52, 52-60.)

Heller, K. A., \& Berndt, T. J. (1981). Developmental changes in the formation and organization of personality attributions. Child Development, 52, 683-691.

村上宣寛・村上千恵子（1999）。性格は五次元だった 一性格心理学入門一一培風館

(Murakami, Y., \& Murakami, C.)

Yuzawa, M., \& Harano, A. (1996). Development of the understanding of character constancy: Expectations of the behavior of friendly and unfriendly peers. Japanese Psychological Research, 38, 181191.

-2004. 4.19 受稿, 2005. 7.9 受理— 